\title{
NOTICES OF BOOKS
}

Essai sur Guṇāọhya et la BRihatkathā suivi du texte inédit des chapitres $x x v i i$ à $x x x$ du NepälaMāhätmya. Par Félix LACôte. Paris: Ernest Leroux, Éditeur, 1908.

It has been for some time well known to Sanskrit scholars that M. Félix Lacôte is engaged in bringing out an edition of the twenty-eight sargas of the Brihatkathaślokasamgraha extant in manuscript form, the first fasciculus of which, containing nine sargas, has already appeared. In the course of his studies he has been led to form a new theory with regard to the original Brihatkatha, the existence of which at one time is now generally admitted. $\mathrm{He}$ finds it necessary to suppose that the poems of Ksemendra and Somadeva, called respectively the Brihat-

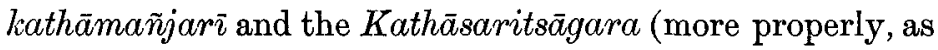
M. Lacôte conclusively shows, the Brihatkathāsaritsāgarasāraślokasamgraha), are based upon a Kaśmīì redaction widely different from the original Brihatkath $\bar{a}$ of Guñadhya. It appears to him that in no other way can the discrepancy between the two poems mentioned above, on the one hand, and the Brihatkathäslokasamgraha, on the other, be accounted for.

This recently discovered poem, which is attributed to a certain Budhasvāmin, and may be called the Nepalese version of the Brihatkath $\bar{a}$, as the MSS. of it came from Nepal, deals, like the two Kasmiri works, with the history of Naravahanadatta, son of Udayana, king of the Vatsas and emperor of the Vidyādharas, but it is compiled in a different form and characterized by a different spirit. It is not a collection of various tales strung loosely on a frame-story, which they render difficult to follow, but 
a simple narrative in which the stories, that are occasionally introduced, arise naturally out of the occasion, and are strictly subordinated to the main action of the poem.

The tone of it is more bourgeois than that of the two Kaśmīni poems. It contains a vivid description of the life of the people, and its colour is eminently local. The neighbourhood of Kauśāmbi seems familiar to the author, and though he takes his hero to other parts of India, his journeys are of the nature of a series of excursions arranged from the land of the Vatsas as a centre. In this respect it forms a striking contrast to the Kathassaritsāgara. It has, I confess, always seemed to me extraordinary that Somadeva, considering that he had undertaken to write the life of Naravähanadatta, king of the Vatsas, should have shown himself so much at home in the geography of Kaśmir, and taken such a faint interest in the country lying round Kausáāmbì.

In order to establish his thesis, M. Lacôte analyses at great length the three principal versions of the Brihat$k a t h \bar{a}$, and briefly notices the Persian and Tamil versions. This, the second section of his essay, is far the longest, and seems to me the most important, as constituting the foundation on which his main theory rests. But, before proceeding to this elaborate examination, he considers it necessary to prove the existence of Gunādhya and the reality of the work attributed to him. In this demonstration he shows himself a most severe critic, and rigorously excludes every doubtful element. As before remarked, the existence at one time of the Paisanci work of Guñădhya is no longer doubted by Sanskritists. M. Speyer appears to take it for granted. In accordance with the completeness which characterizes all his work, M. Lacôte goes once more thoroughly into the question. In addition to the references brought forward by Hall, Bühler, and others, he has found some of special interest mentioning the name of Naravāhanadatta, which does not often occur 
in general Sanskrit literature. One adduced from Daṇdin's Daśakumāracarita runs as follows :- "Viraśekhara, son of Mānasavega, grandson of King Vegavat, had for an hereditary enemy the actual emperor of the Genii, the vigorous offspring of the king of the Vatsas, Naravāhanadatta." Subandhu in his Văsavadatta mentions Naravāhanadatta in the course of a comparison. The Dasarupa of Dhanañjaya defines the permanent sentiment (sthāy $\bar{\imath} \quad b h \bar{\alpha} v a)$ as that which is not supplanted in the course of the action by analogous or opposing sentiments, and Dhanika's commentary on that work, called Avaloka, gives as an instance the love of Naravāhanadatta for Madanamañjūșā, the Madanamañcukā of the Kathassaritsāgara and of the Brihatkathāmañjarī, and the Madanamañjūkā of the Brihatkathas'slokasamgraha. All these writers, of course, preceded Somadeva and Kṣemendra.

M. Lacôte sums up the state of the question before the discovery of the Brihatkathaslolkasamgraha in the following: words:- "At the point which criticism had now reached, we had the right to assume in the first place the existence of the Brihatkath $\bar{a}$ of Gunädhya at an ancient epoch, and in the second place the existence of a compilation imitated by Somadeva and Ksemendra, but the relation of this compilation to the original Brihatkath $\bar{a}$ still remained to be defined."

It is here that the Brihatkathasslokasamgraha comes in and suggests the true solution of the enigma. It renders more tangible the reality of the Brihatkath $\bar{a}$, and at the same time shows the utter untrustworthiness of the Kaśmini version as a reproduction of it. Although its relationship to the Kathāsaritsāgara and the Mañjar $\bar{z}$ is obvious, it differs from them so profoundly that we cannot assign to it the same original. At the same time its title indicates that it is based on a preceding work, and that follows also from internal evidence. Though it only mentions Gunādhya once, and that incidentally, it supposes 
the main story of the Brihatkath $\bar{\alpha}$ to be known to every one. For instance, when, near the beginning of the story, a celestial messenger announces to the hermits assembled on the Black Mountain, that the emperor of the Vidya dharas is coming next day to visit his uncle, how would one know that the personage in question is Pälaka, the brother of Vāsavadattā, without being familiar with Gunădhya's poem? Nothing proves more clearly the long popularity of the Brihatkath $\bar{a}$.

In order to give an idea of the minute examination to which M. Lacôte subjects the two Kaśmīī compilations, I desire to call attention to a new translation which he gives of the vexed passage in the Kathōsaritsāgara i, 10-12. After reviewing all the translations that have been given he brings forward one of his own. He considers that the words kāayāmśasya yojanā refer to a re-arrangement by Somadeva of books 14-15 (Pañca and Mahäbhiseka), which bear to a certain extent the character of a kāvya, and that this is the effort (ayam udyamah) referred to in verse 12. This accounts for the fact that Somadeva's arrangement of the books differs slightly from that of Ksemendra. M. Lacôte holds the view that Kṣemendra, being, as a literary workman, inferior in all respects to Somadeva, did not presume to modify the order of the Kaśmiri Brihatkatha. He retained it with all its defects. Some defects are common to both compilations. In both there is an utter want of systematic arrangement in the main narrative. A minor defect is the continual repetition of stories. For instance, the story of Unmādini is repeated three times by Somadeva and twice by Kṣemendra.

M. Lacôte supposes that the Kasmiri Brihatkath $\bar{\alpha}$ was thus constituted. It must be supposed that an abridgment of the original Brihatkath $\bar{\alpha}$ was in circulation in Kasmir. This abridgment received a modification by the insertion of the story of Kalingasena, or by a great extension of its length. 
The next step was to incorporate in the abridgment other famous stories which were supposed to be extracts

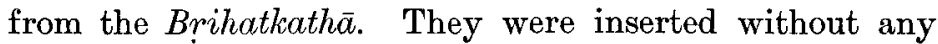
attempt to harmonize them with their surroundings. The next was to introduce all famous tales, whatever may have been their origin, making use of such simple formulæ as "Hear what Gomukha related", or "Hear what was told to Naravāhanadatta".

When the Brihatkath $\bar{\alpha}$ of Kaśmir has been constituted with approximate certainty by a comparative analysis of the Kathäsaritsāgara and the Brihatkathämañjari, and when it has been shown that the Slokasamgraha of Budhasvāmin differs considerably from it, the question naturally arises which of the two redactions is most faithful to the original Brihatkathā ? M. Lacôte elects for the Nepalese version, as against that of Kaśmir. It explains many of the inconsistencies of the other two poems, and it is in itself a coherent and intelligible narrative. For instance, its realistic treatment of the story of Kalingasenā, whose name suggests her real position in life, is evidently in accordance with the original plan. Somadeva's version of this lady's adventures is confused and inexplicable without the hints given by the Ślokasamgraha. We are driven to the conclusion that the Kaśmiri version has not only amplified by the insertion of inapposite tales, but also, so to speak, ennobled the original substratum. Its social atmosphere has been elevated. Merchants have been turned into princes, and for the middle-class god Kuvera (or Naravāhana) the more aristocratic god Siva has been substituted. The theory of M. Lacôte is most ingenious and fascinating, but some may be found to regret that there is no clue to the date of Budhasvāmin's poem, and to long that further light may be thrown on the subject by the discovery of the remaining sargas. At any rate, no one can read the nine sargas already published without agreeing with M. Lacôte 
in his opinion that the actual life of the people is therein vividly portrayed, and that their author shows a veritable enthusiasm for Realien. In this respect it compares favourably with the artificial poems which we are taught by Indian pandits to admire.

But though the tales loosely attached to the main narrative of the Kathassaritsägara may diminish its value as a work of art, they must possess an abiding interest for the student of comparative folk-lore.

Moreover, we have the testimony of educated Indians to the fact that they do in some instances illustrate the everyday life of their countrymen. M. Speyer has drawn attention to the poetical merits of Somadeva's work, and if we object to the confused arrangement and inconsistencies of his narrative, can we claim that our own poet Spenser is in this respect immaculate?

Whatever may be thought of M. Lacôte's main thesisand it must, I think, be admitted to be very probablethere can be no doubt that his essay is characterized by a variety of illustration and a profound erudition which must render it most instructive to every student of Sanskrit literature.

Before taking leave of his subject M. Lacôte proceeds to consider the sources of the Brihatkatha $\vec{a}$ He comes to the conclusion that Udayana is a local hero. He shows from Buddhist sources that there were local legends connected with him, as well as with Pradyota, Bimbisāra, and Prasenajit. These legends the Buddhists utilized, after their manner, for the purpose of edification. He conjectures that the Brihatkatha was composed in order to be recited before the crowds, that the festival of udakadannaka attracted to Ujjayini, and the $y \bar{a} t r \bar{a}$ of Nàgavana drew to Kausámbi. It is not, of course, suggested that Gun̄ạdhya examined the Buddhist legends in the written form in which they have come down to us, but he picked them up in the localities where the Buddhists found them. 
M. Lacôte goes so far as to suppose that Gunādhya may have been influenced by the writings of Greek novelists who were really Asiatics writing in the Greek language. It does not appear to me to be certain that in this case the Indians were the borrowers. The Metamorphoses of Apuleius, though written in Latin, closely resemble Indian tales. Perhaps the influence of India extended even to Africa. M. Lacôte's suggestion is, at any rate, interesting and opens out wide prospects. To show that the influence of Guñạhya is traceable in subsequent Indian literature M. Lacôte points especially to the Daśakumāracarita and the Mricchakatikā. Though the Dasakumāracarita has been influenced by the rhetorical schools, it represents an India more active, more varied, and more full of the joy of life, than we find in the

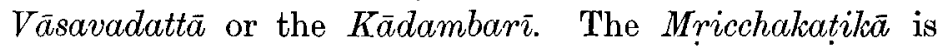
admittedly the most living work of the Indian theatre, and it is full of the spirit of the Brihatkathã. It is a pity, remarks M. Lacôte, that Indian comedy was not continued on these lines.

By way of conclusion to his work, M. Lacôte prints in the original Sanskrit the legend of Guñạhhya as found in the Nepālamāhātmya. It does not differ materially from that found at the beginning of the Käth $\bar{a}$ saritsāgara.

C. H. T.

Hindu Tales. An English translation of Jacobi's Ausgewählte Erzählungen im Mahārāshțrī, by JoHN JACOB MeYER. London: Luzac \& Co., 1909.

Dr. Meyer tells us that he undertook the translation of the Tales edited by Geheimrat Professor Jacobi at the suggestion of Professor Lanman. Professor Jacobi intended his edition of these stories to be an introduction to the study of Prākrit, but Dr. Meyer has apparently a double object, to aid the beginner in Prākrit and to 